\title{
Balandú, voz poética de Manuel Mejía Vallejo
}

\section{Eliana María Urrego-Arango / Universidad Pontificia Bolivariana}

Cada autor tiene una voz, un ritmo propio, una imagen que lo acompaña y da color a su creación. Cada autor nos entrega una poética, el sello personal de su obra. En el proyecto creativo del escritor antioqueño Manuel Mejía Vallejo (19431998) la aldea llamada Balandú es el centro, el núcleo sobre el cual giran sus personajes, sus tiempos y sus historias. En ese lugar, ubicado en un espacio similar al del suroeste de Antioquia, a imagen y semejanza de Jardín, pueblo de origen del escritor, se enlazan la memoria personal del autor y la ficción. Esta aldea andina es el territorio que habita la familia Herreros, colonizadora, fundadora y una de sus estirpes principales. La historia de los Herreros está marcada por una maldición que se renueva en cada generación, como recordatorio de la imposibilidad de evadir su destino trágico. Los personajes están anclados de una u otra manera a Balandú, así se alejen del pueblo, su corazón sigue viviendo en sus calles empedradas, en medio de la niebla espesa y sus casas solariegas. Este espacio será el territorio ficcional clave del escritor: allí se desarrollan tres de sus novelas y dos libros de cuentos; además, en sus novelas urbanas se refiere como el lugar del que se sale en busca de un mejor futuro y al cual se quiere volver. ${ }^{1}$ Balandú hace que la obra de Mejía Vallejo se convierta en una novela total, en los términos que usa Vargas Llosa (2007): una de "esas creaciones demencialmente ambiciosas que compiten con la realidad de igual a igual, enfrentándole una imagen de una vitalidad, vastedad y complejidad cualitativamente equivalentes" (9).

Es fácil evocar las semejanzas con Yoknapatawpha, Macondo o Comala (Corbatta 2000, 379). La aldea de Mejía Vallejo traslada a la región andina esta tradición de universos imaginarios que dan cuenta de América, desde el sur estadounidense hasta el Caribe colombiano. Balandú narra la vida en la cordillera, imperiosa y sagrada, entregándonos una visión singular del mundo. En este artículo se propone una lectura de la voz poética del escritor antioqueño a partir de su pueblo imaginario, articulando su apuesta estética en torno a tres puntos: la espacialidad simbólica, las imágenes de la tierra y el pensamiento andino. Para abordar estos puntos nos valdremos de las teorías del imaginario de Gaston Bachelard y del pensamiento andino propuesto por Josef Estermann.

\section{La espacialidad y la materia imaginaria}

La memoria y la imaginación entretejen con sutil delicadeza sus fibras para dar origen a la imagen literaria, creación subversiva del orden establecido que nombra la realidad desde una verdad que trasciende la apariencia. Balandú surge de los recuerdos de infancia de un hombre que transforma esas reminiscencias en palabras que dan vida a un mundo. La aldea es espacio recreado, tal como lo señala Mejía Vallejo en una conversación con Augusto Escobar: "Soy un poco reiterativo en el regreso a la infancia, porque creo que hay una especie de estética del recuerdo; hay una recuperación, un ahondar en un mundo vivido por uno" (Escobar 1997, 157). Alejándose de una concepción del espacio demarcada por los sentidos, capturada y nombrada desde formas comprobables, Balandú se recrea a partir de la imagen ensoñada que deforma lo percibido y transforma lo real enunciando lo ausente. El pueblo se configura como lenguaje e imaginación simbólica, esa cualidad que Durand (1971) reconoce en "el semantismo de las imágenes, el hecho de que no son signos sino que contienen materialmente, de alguna manera, su sentido" (61).

Las palabras que crean una imagen no son exactamente la realidad que nombran; de esta manera, los objetos se convierten en otros. La palabra es esa construcción que el hombre arma intentando acortar la distancia que lo separa de la realidad exterior. No toda palabra, por tener este destino metafórico, es imagen poética. La imagen poética busca trascender el habla, violentar el lenguaje, desarraigarlo, restarle objetividad. Se subjetiva en tanto las palabras se organizan para trasmitir un sentimiento, una emoción o un estado espiritual. En otros términos, lo poético carga la realidad con otros sentidos, como afirma Paul Valéry:

Entonces esos objetos y esos seres conocidos cambian en alguna medida de valor. Se llaman unos a otros, se asocian de muy distinta manera que en las condiciones ordinarias. Se encuentran -permítanme esta expresión- musicalizados, convertidos en conmensurables, resonantes el uno por el otro. (1990, 137)

Cuando Mejía Vallejo comienza a narrar el pueblo de su infancia, este deja de ser el municipio situado en un lugar particular del mapa político colombiano, registrado bajo el nombre de Jardín. El pueblo es desarraigado de esa realidad objetiva y pasa a ser Balandú, una imagen que contiene los valores que el escritor le otorga. El espacio se convierte en un universo imaginario con una carga simbólica particular: "Por un instante Balandú va llenándote, sus calles, su geografía, su luz intermitente" (Mejía Vallejo 2002, 193). El creador de un mundo compone el espacio al configurarlo como 
imagen, "y la imagen al verse y reconstituirse como imagen crea una sustancia poética" (Lezama Lima 1981a, 218). Es decir, la imagen se sabe representación, enuncia en presente lo ausente, rebasa el significado del lenguaje: es poética porque nombra aquello que en el habla resulta imposible de decir. En cuanto un espacio imaginado se carga con un valor crece simbólicamente, se convierte en materia estética, en espacio poético. Alba Doris López (2011) nos propone que la espacialidad de Balandú se configura como un cronotopo que modela la acción de los personajes y funciona como depositario de la historia familiar y de todo un legado cultural que ella trasmite (178). La imagen de este pueblo se configura en gran medida a partir del valor que le da el recuerdo; por un lado, unos personajes que viven rememorando su mundo, su historia familiar y, por otro, un espacio narrativo que representa el origen perdido y que es necesario volver a cantar para recuperarlo (Gallego-Duque 2017, 69).

Balandú refleja la infancia, la vida en la montaña, la familia, el lugar sagrado del origen, las reglas sociales impuestas, el desacato de las mismas, la tragedia vital de la finitud y el miedo al olvido. Balandú es ante todo memoria: la del escritor y la de una época de Antioquia. Por esto el autor utiliza imágenes puntuales, formas del recuerdo, para describirlo, así como un sonido cotidiano: "Si vas a un pueblo donde se oye por lo menos el cascoteo de un caballo sobre las piedras, ese es Balandú"; un sentimiento compartido: "Si notas que el amor te hiere y se estanca en el corazón olvidado, eso es Balandú"; el contraste de creencias: "Si detrás de unos muros blancos sale un rezo coral de convento, ese es Balandú; si oyes canciones trasnochadas delante de unas orejas de prostíbulo pobre, ese es Balandú"; y la intuición del propio fin: "Si crees estar en el largo día de difuntos y sabes que las campanas doblan tu muerte, conocerás a Balandú, otra muerte más sobre tu muerte" (Mejía Vallejo 1984, 50).

Lezama Lima explica la poética como aquella "región de la poesía donde este es aquel, donde es posible reemplazar el escudo de Aquiles por la copa de vino sin vino, ese árbol por aquella hoguera" $(1981,276)$. Una poética del espacio se refiere al entretejido de imágenes en que los lugares son despojados de sus sentidos más corrientes y llevados al terreno de la ensoñación. Al cantar un territorio el poeta parece lanzar una imagen que atraviesa por completo su propuesta creativa. Bachelard (1958) nos dice que cada escritor nos debe su invitación al viaje: "Si la imagen inicial está bien elegida, se revela como el impulso hacia un sueño poético bien definido, a una vida imaginaria que tendrá verdaderas leyes de imágenes sucesivas, un auténtico sentido vital" (12). Mejía Vallejo formula esta invitación al viaje desde su primera novela -La tierra éramos nosotros (1945)-, donde vemos el motivo del pueblo, que se articula a partir del regreso al lugar de infancia y el duelo por perder aquella forma de vida. Narrar la aldea, configurarla como imagen literaria de un tiempo que se vivió, dar vida a los seres y objetos que se almacenan en la memoria, será la obsesión más constante en la creación de nuestro escritor, como él mismo comenta:

Tal vez escribo por un lejano instinto de conservación, por vanidoso temor de esfumarse completamente, de que seres y cosas que atestiguaron mi camino de hombre lleguen a morir en mi propia muerte; la obra sería un rastro que dejo, retazos de historia que viví y que me obligaron a soportar; un deseo ingenuo de cambiarla. (Mejía Vallejo 1985, 3)

Esta cita nos muestra cómo el escritor tiene una intención de dejar constancia del mundo que ha vivido; sus recuerdos y la visión que quiere entregar se enriquecen al hacerse imagen literaria. En términos de Bachelard (1958), dichos recuerdos muestran un onirismo novedoso que significa "otra cosa y hace soñar de otro modo, tal es la doble función de la imagen literaria" (306). Para explicar este punto recurrimos al concepto que Durand (2004) denomina "trayecto antropológico, o sea, el incesante intercambio que existe en el nivel de lo imaginario entre las pulsiones subjetivas y asimiladoras y las intimaciones objetivas que emanan del medio cósmico y social" (43). Ello indica que las imágenes ensoñadas o los símbolos imaginarios mantienen una relación básica con percepciones de la realidad bio-física y social, se configuran en una asimilación entre los esquemas subjetivos y los datos. La vieja palabra se renueva en este proceso de asimilación donde se pone en juego aquello que rodea al sujeto, lo arquetípico y lo subjetivo. Podemos decir que las ideas son animadas por la imaginación material; esto se refiere a uno de los dos ejes que Bachelard (1978) propone como articuladores de nuestras fuerzas imaginantes: forma y materia. El primero viene motivado por una "imaginación formal," se ocupa de la apariencia, de la belleza formal, la superficie; el segundo es motivado por la "imaginación material," aquello de lo que están hechas las imágenes, lo primitivo e imperecedero, una materia básica y constante. Por sus distintas funciones, la imaginación literaria necesita de ambas fuerzas, de la metáfora y de la intimidad sustancial que se revela en dicha forma.

Balandú es narrado en un lenguaje formal con un fin estético, es aquello que primero se nos presenta al leer: la superficie a través de la cual accedemos a las imágenes que hay detrás, en lo más profundo, y que componen las raíces de la imaginación, su materia. En las imágenes materiales podemos ver los cimientos simbólicos de ese carácter mítico y simbólico que caracteriza el universo literario de Mejía Vallejo. Revisemos este diálogo, en el que un personaje le cuenta a otro sobre la ubicación de Balandú, señalando la importancia de la niebla en el paisaje:

- Y ese Balandú tuyo, ¿dónde queda?

- Entre la neblina.

- Eso no es una dirección. 
- Es la dirección de Balandú, el país de la niebla.

La que sube por los arroyos, la que baja por los páramos, la que rodea a cada persona, la que va dejando el recuerdo. La del olvido cuando se pierde el amor en otras nieblas, las que al evaporarse dejan los llantos solos. (Mejía Vallejo 2002a, 90-91)

La neblina simboliza la ausencia, lo que se hace evanescente. En una característica espacial se exponen la nostalgia y el llanto. Cuando un poeta canta, plantea Bachelard, es fiel a un sentimiento humano primitivo y en sus imágenes demuestra esta lealtad. Para explicar esto, Bachelard recurre a los cuatro elementos - tierra, agua, fuego y aire-, paradigma de las filosofías tradicionales y de las cosmologías antiguas, que demarcan las materias de las imágenes, pues actúan como símbolos elementales en la configuración de una poética. Se necesita de los cuatro a la hora de hacer literatura: todos se complementan, mezclan y dinamizan en la creación. Sin embargo, la poética propia de cada autor da primacía a uno de ellos, ya que las imágenes más recurrentes de cada uno están cargadas de sus propiedades: es fuego (luz, calor); agua (fluidez, profundidad); aire (movimiento, vuelo); o tierra (dureza, oscuridad). Para que una meditación se convierta en una obra escrita "debe hallar su materia, es necesario que un elemento material le dé su propia sustancia, su propia regla, su poética específica" (Bachelard 1978, 11), otorgándole consistencia a la voz y el estilo del escritor.

Balandú es un espacio que se ordena a través de símbolos que dan cuenta de los diversos elementos. Mejía Vallejo recurre al fuego en forma de luz, cobijo, calor o incendio para nombrar afectos: "No son luces que se meten en la oscuridad: son oscuridad que se mete por la luz para comérsela: iluminan mientras se alimentan de la luz, pero tras de sí van dejando una oscuridad angustiosa" (Mejía Vallejo 1994, 169). E1 fuego, como voraz destructor, consume una de las casas de los Hereros, símbolo de las pasiones desmedidas, edificación también arrasada por la fuerza del agua que sofoca las llamas y muestra los impulsos incontenibles: "Por momentos el río retrocedía, por momentos se metía en los pilares y arrastraba el corredor cercano, un ángulo del balcón, tejas y macetas" (Mejía Vallejo 1990, 198). Frescura, transparencia, reflejo, turbulencia, fluidez, mansedumbre o desborde son los epítetos del agua, los cuales se encarnan en espacios, objetos y fenómenos naturales de Balandú. El aire es viento, nubes, alas, vértigo, salto del pez, trayectoria de la flecha, cielo, vuelo de pájaros e insectos. En Balandú el aire es un elemento fundamental a la hora de relatar la ascensión a las montañas, el batir de los árboles, la contemplación de las aves o el rumor de las voces ancestrales: "Remolinos de noche y nada, rebullones de vacío, ausencias extraviadas, cansadas, desoladas. Se alejan, avanzan en huracán, ventisca, brisa, sombra, espirales estancados, aire quieto" (Mejía Vallejo 2004, 437).
Si bien en la obra de Mejía Vallejo encontramos imágenes de los tres elementos anteriores, la inclinación poética principal del autor radica en la tierra: en las imágenes de la resistencia, de la batalla que transforma la naturaleza, de la raíz o de la montaña, donde se sustenta su inspiración. Lo podemos observar en frases como esta: "La tierra es fuerte, la montaña es más fuerte que el hombre. En ella iban quedando, otros árboles al golpe del hacha" (Mejía Vallejo 1990, 112). La tierra ligada a la gran cordillera, eje geográfico de este universo, será el insumo primario del escritor, la materia que caracteriza y entona su voz poética.

\section{Poética de la tierra}

La tierra es gravedad, sustento vegetal y mineral, refugio y vientre que alberga semillas. Es un elemento que tiende a la estabilidad, requiere del esfuerzo humano o de un despliegue de las fuerzas de la naturaleza para dinamizarse; a la tierra podemos sentirla en nuestras manos, en nuestros ojos, la transforman nuestra intención y nuestra piel. La tierra despierta en el ser humano la voluntad de poder, el instinto de dominar la materia con el trabajo, la dialéctica de lo duro y lo suave que vence su primera característica: la resistencia. Este ensueño se ve conformado por diversas imágenes, como las de las minas, la orfebrería, la herrería, la labranza, las herramientas, la masa, así como la del hombre que contempla en la cima de una montaña su terreno dominado: "Desde el balcón oteaba sin saber qué [...] Vano empeño del hombre ese de vigilar su tiempo: cada día traería su afán y cada afán su propio enredo. El paisaje también siguió en expectativa" (Mejía Vallejo 1990, 142). Es propio de la tierra movilizar, también, hacia lo profundo de las cosas, voluntad de ver al interior de los objetos, el sueño del reposo enraizado que tiene la intensidad de lo íntimo (Bachelard 2006, 15). Esto se aprecia en el siguiente pasaje, donde Mejía Vallejo (2002) narra el sentir de una mujer encerrada en la casona del pueblo: "Como a nadie hablaba de penas, el monólogo se hizo más sólido bajo las cobijas, mordiendo la almohada, desvelándose ojerosa frente al espejo del tocador" (107). Esta interioridad prioriza imágenes como la gruta, el vientre, las tinturas, la serpiente, la semilla, la raíz, la casa soñada, el huerto y el laberinto.

Cuando el espacio es poetizado por una imaginación terrestre se da un valor a varios motivos que se observan en nuestro pueblo imaginario. Balandú es colonizado, fundado por hombres que se abrieron camino en la cordillera; vive de la labor del que siembra café, cuida el ganado o excava en la mina; de las mujeres que bordan y de las manos que trabajan la madera que cerca sus balcones. Balandú se recrea en los rincones donde la familia Herreros conversa, canta bambucos, cree en el poder de cristales y rocas; también en las estatuas que cobran vida y en los muertos que salen por los espejos para recordar las maldiciones de los ancestros: "En el espejo está la bravura, toda la historia, todo el remordimiento. 
¿Cuál claridad? El espejo es la noche, detrás del espejo vigilan fantasmas" (Mejía Vallejo 1980, 120). El cristal de los espejos se convierte en un símbolo fundamental de este espacio ficcional, un puente de comunicación entre los personajes del presente y los ancestros. La propiedad de dicho cristal de fijar los rostros y los acontecimientos es asumida como la pantalla donde el recuerdo regresa y teje un diálogo con el pasado. El espejo es un espacio duro, firme, aunque frágil, siempre enmarcado, establecido en un lugar puntual que le agrega sentido. La característica de profundidad que permite el reflejo en esta superficie se hace metáfora del acto de ver en la imagen especular de toda la historia familiar, es el objeto que muestra quiénes son.

La tierra cifra la identidad de la familia Herreros: los personajes se nombran a sí mismos como habitantes de Balandú, herederos de los transformadores de ese paisaje, de quienes dominaron el territorio. Son ellos quienes construyen y toman las decisiones, se sienten culpables y responsables de lo que acontece en esos parajes: son los dueños. En esta reflexión de Efrén Herreros, quizá el personaje más trabajado por el escritor en su saga familiar, es posible comprender esta forma de identificación con el territorio:

Había en él una conciencia de habitar las tierras altas donde el frío era temperatura normal, y de habitar las tierras bajas, donde el calor se pintaba con exuberancia en esa geografía vulnerable. La zona tórrida, el impulso a la locura del paisaje, otra posibilidad de ascenso o de caída.

-Eso somos, nada más.

Pero creía en la gente y en su medio, y se conmovía al habitarlos.

-Es nuestra tierra, nuestra dura y hermosa tierra.

Y la quería al compararla, al sufrir, al aborrecerla y amarla en su desgarramiento.

-Esto nos ha tocado. (Mejía Vallejo 1990, 111)

En esta cita se nos muestra cómo el estar en la cima de la montaña o estar en pie se convierten dentro de la obra en símbolos del ascenso o la caída. La familia, que se ha visto envuelta por las maldiciones, recorre en repetidas ocasiones ese camino de arriba abajo, se balancea entre el subir para verlo todo con claridad y el descenso desenfrenado al abismo, donde el sufrimiento los abruma. En este punto coincido con Félix Duque-Gallego (2017a) cuando afirma que en la narración de Balandú "los climas, la geografía y los espacios se anudan a las pasiones que mueven a sus personajes centrales: los Herreros" (41). Los sentimientos familiares son nombrados no solo por su comunión con la tierra, sino desde los rasgos característicos de esta como elemento poético.
Esto se consigue al combinar lo telúrico con propiedades de otros elementos: la tierra se mezcla con el viento, el agua y el fuego para dar origen a imágenes compuestas con mayor dinamismo y complejidad, como ésta, en la que un personaje en un estado desesperado, atosigado por las culpas propias y heredadas, expresa: "Atajen el viento -decía señalándolo-. El viento trae las voces de ultratumba, también el viento se vuelve fantasma" (Mejía Vallejo 2002, 162). El aire volátil y libre queda capturado por las voces de ultratumba, sonidos de la tierra profunda que representan a los muertos y que les dan naturaleza de fantasmas, imagen mixta que narra la desazón de sentirse asediado. Esta alquimia de los elementos nos permite concebir momentos de mucha intensidad, gracias a los cuales se pueden identificar en la narración de Balandú una serie de dimensiones, con un sentido más metafísico que geométrico, donde no operan las medidas porque lo que se intenta fijar es la espacialidad del ser. Se diferencia dentro y fuera, abierto y cerrado, delimitaciones de lo íntimo y lo ajeno, que establecen límites y dictaminan lo prohibido. En fragmentos como el siguiente observamos cómo el escritor, desde la construcción de la espacialidad de los objetos, narra el silencio de una casa y la soledad, pues justamente el pasaje aparece en un momento en el que ya solo quedan los últimos de la estirpe:

Otros ruidos se encerraban en sus objetos desde tiempo atrás, porque no volvió a caer un trasto, a correr un mueble, a forzarse una puerta: si golpearan o cayeran al suelo, caerían o golpearían o se quebrarían silenciosos porque en ese encierro de años habían olvidado su propio sonido. (Mejía Vallejo 1980, 9)²

Resalto los verbos usados: golpear, caer, forzar, quebrar, encerrar. Son acciones de corte telúrico, de propiedades ligadas a la dureza y la fuerza. Muchos de esos verbos son empleados también para describir el pueblo en los oficios más reconocidos: la herrería, la barbería, la carpintería, la zapatería. Dentro de las narraciones también aparecen verbos que nombran la mirada sobre el paisaje: contemplar, otear, divisar, atisbar. La imagen de un hombre que desde la cima de una montaña lo observa todo, propia de la poética terrestre, es reiterativa y, por tanto, parte esencial de la construcción espacial. En las novelas de Mejía Vallejo puede entenderse como símbolo de dominio o de admiración y amor a la naturaleza, además es uno de los gestos que caracteriza a Efrén Herreros: "Miraba el vuelo de las palomas hasta el farallón y su regreso circundante a los palomares (...) Él recreaba el mundo con su mirada nueva y propiciaba el vigor de la piedra y la montaña" (Mejía Vallejo 1990, 402-403).

En Balandú la imagen que nos muestra con más fuerza la simbología terrestre es la casa. La casa es construcción anclada al suelo, imagen del refugio, del reposo y de las labores del hogar. Se dinamiza a su vez con otros elementos: el agua y el fuego en la cocina, con la chimenea del salón, con la brisa que corre trayendo el frescor y los olores. Este espacio 
tiene la particularidad de conectar el cielo y la tierra, actúa como un vector vertical que tiende al ascenso, a la elevación, tanto como a la caída y al arraigo. En su imagen plena, la casa también es un centro, la raíz de la que emergen todos los acontecimientos; es símbolo de la intimidad, la casa es el núcleo del universo (Bachelard 1975, 78). En la verticalidad y la centralidad radican las fuerzas de una casa, su estabilidad o enraizamiento, su posibilidad de proyectarse más allá del terreno donde está edificada, su potencial ominoso y, por supuesto, su capacidad de protección y cobijo. La Casa de las dos Palmas, la Casa del Río y la casona del pueblo son las moradas de los Herreros, sus puntos de referencia. Al conectar todo el universo imaginario del escritor, dichas casas funcionan como referentes simbólicos.

La Casa del Río, en la parte baja del pueblo, será el lugar del descarrío; la casa del pueblo es espacio siempre habitado, lugar del cuidado casero, donde se va a reposar y a recordar; la Casa de las dos Palmas, ubicada en la altura del páramo, es el centro familiar más importante, símbolo de poderío y de la primera maldición. Todas estas moradas adquieren un sentido importante dentro de Balandú, si bien es la Casa de las dos Palmas la que Bachelard (2006) llamaría la casa onírica:

La casa onírica es una imagen que se vuelve, en el recuerdo y en los sueños, una fuerza de protección. No es un simple marco en el que la memoria encuentra sus imágenes. En la casa que ha dejado de ser nos gusta vivir todavía porque en ella revivimos, muchas veces sin darnos bien cuenta, una dinámica de confortación. (138)

La Casa de las dos Palmas es el sueño arraigado en la memoria de la familia, la casa de la infancia, el espacio donde se consagra el mito de los fundadores. Representa el nacimiento de una estirpe a la par que su maldición y extinción: "¡A la Casa de las dos Palmas! A un modo de regreso al origen. Aquí llegaron ellos para su aprendizaje de muerte, aquí mismo en cada día y en cada acto ensayaron su hundimiento" (Mejía Vallejo 2002, 50). La Casa de las dos Palmas actúa como centro simbólico del universo literario. Es el punto articulador de los personajes, de la historia y del tiempo. A través de ella se va construyendo una poética del espacio, su imagen potencia la del páramo, la montaña, los árboles, los salones y corredores. El pueblo existe en referencia a esta casa en lo alto, hacia la que se mira para ensoñar dulces tiempos o las más terribles pesadillas. En la Casa de las dos Palmas encontramos ese lugar primero, la añoranza del tiempo perdido, el mito, la imagen donde el autor consigue reunir lo poético y lo imaginario. Así la invoca uno de los últimos de la estirpe:

Te invoco ahora en todo lo que fuiste, Casa de las dos Palmas, esperanza amarga del Fundador, refugio de la pena, creadora de amargura, hospital de desahuciados, cueva de poseídos, silencio de cosas difuntas, cómplice del crimen, tumba de alaridos sin respuesta. ¡Invoco tu presencia fantasmal, Casa de las dos Palmas! Que me hablen los espejos y que los espejos repitan lo que están hablando. (Mejía Vallejo 1980, 165)

En esta invocación, la casa se nombra como refugio, esperanza, lugar de amargura, cueva, tumba o espacio de la muerte; se pide a los espejos que allí residen que digan algo sobre la memoria. Así, esta vivienda queda cargada con los valores de la tierra que alberga, que es caverna y sepulcro; que ha fijado la memoria de los Herreros en el cristal especular, como nos confirma una vez más esta cita: "Los [espejos] de La Casa de las dos Palmas saben historias y adivinan el futuro y encierran en sus cristales esos presentes que nunca dejan de ser eternos" (Mejía Vallejo 1980, 165). A las casas como símbolos que recogen la historia familiar se suma la presencia constante de la montaña y del río, referentes clave a la hora de entender este territorio imaginado. Por ello, en la asociación con las viviendas familiares, ambos referentes configuran una espacialidad simbolizada, donde la altura de la montaña y el descenso al río representan la dinámica familiar de ascenso y caída.

Ese transcurrir de imágenes, esencialmente terrestres, es más bien un devenir de espacios en el que se logra encadenar el tiempo. El escritor poetiza el espacio metaforizando estados del alma, complejidades de una intimidad que se tambalea entre lo real y lo onírico (Mejía Arango 1996, 4), narrando sensaciones y sentires propios del habitar la cordillera. Esta creación nos lleva al interior de la gran cadena montañosa y nos enseña la potencia de la tierra que emerge como monte sagrado, que da sustento íntimo a la semilla que despierta. La voz terrestre del escritor trae así las resonancias de las alturas andinas.

\section{El mundo andino}

Las imágenes de la tierra que dan soporte a la obra de Mejía Vallejo nos invitan a un viaje por un territorito ordenado y habitado desde el pensamiento andino. El paisaje que se dibuja en las novelas no solo da cuenta del espacio ubicado en la cordillera de los Andes, sino que también nos señala su organización espacial, temporal y su visión de mundo. Hablar de lo andino es complejo. Aunque suele asociarse a una visión indigenista, dicho vocablo implica una reunión de varias formas de vida (campesina, urbana, indígena, mestiza, española) que habitan esta geografía y que se vinculan a través de unas maneras particulares de entender la realidad. Según Josef Estermann (2006), el término "andino" hace referencia "a un cierto modo integral de vivir, es decir: a una determinada 'cultura'. Lo 'andino', derivado de la acepción geográfica, se ha impuesto sobre todo como una categoría cultural" (61). Esta concepción no desconoce la diversidad de pueblos, costumbres, creencias, organizaciones políticas y lenguas que 
conforman la región. Al contrario, señala en esta pluralidad de elementos una mirada común articulada en torno al lugar que se comparte:

El espacio geográfico y topográfico de los Andes es determinante en parte para la elaboración de un pensamiento filosófico propio, tal como lo eran también - mutatis mutandis - el paisaje costeño en Jonia para la filosofía griega o la región fluvial del Ganges para la filosofía índica. (Estermann 2006, 60)

En la narrativa de Balandú encontramos tres características importantes del pensamiento andino: la verticalidad en la espacialidad, la concepción cíclica del tiempo, y la interrelación de toda la naturaleza ${ }^{3}$. El espacio se organiza en la dialéctica de arriba y abajo, no hay una correspondencia con los puntos cardinales, allí "existen dos fuerzas, la cósmica que viene del universo, del cielo (pachakama o pachatata); y la fuerza telúrica, de la tierra (pachamama). Las dos energías generan toda forma de existencia" (Huanacuni 2005, 3). Esta verticalidad que comunica al cielo con la tierra tiene como punto de referencia la montaña, la cual funciona como Axis mundi: centro del cosmos. ${ }^{4}$ En su cima, lugar celeste, Mejía Vallejo nos habla de un clima frío, de una vegetación agreste cubierta por la niebla o la lluvia. El escritor sitúa allí la Casa de las dos Palmas, espacio sagrado para la familia Herreros, al que se mira en busca de referentes que orienten la vida. Este territorio, que en las novelas del autor recibe el nombre de páramo, alberga animales y plantas imaginarios. El páramo permite asimismo la comunicación con los ancestros: es el refugio de seres perdidos que sufren y quieren alcanzar la paz, lugar de conexión con la espiritualidad personal y familiar. El camino a las tierras altas se emprende en momentos de desolación, de reunión filial y reflexión vital. Todo allí es imagen de la altura: "Los farallones echaban arriba sus fauces como tratando de morder el cielo, y la montaña extendía su lomo para que la sobara Dios con su mirada" (Mejía Vallejo 1990, 45). Desde lo alto se divisa el mundo, los ojos pueden ver más allá después del ascenso a la montaña, como si el trabajo de subir se recompensara con dicha percepción.

En la mitad de la montaña se halla el pueblo de clima templado, con su realidad política, social y económica, y un orden que responde a una lógica distinta a la sacralidad del páramo. Aquí se encuentra el caserón familiar, construido en el solar que les fue entregado a los Herreros en tiempos de la fundación. Es un rincón donde los personajes hacen memoria, intentan comprender las experiencias vividas en la altura, o descansan antes de emprender la subida. Se trata de un espacio siempre habitado que ofrece cuidado y protección, pero también es un lugar estático que repite fórmulas sociales, obedece al deber ser impuesto por la religión y los poderes del momento. Como vemos en la siguiente cita, las imágenes del pueblo reflejan la vida de una aldea conservadora, donde la quietud y la rigidez se enfatizan al decir que sus habitantes están "aldeados", unidos por completo a aquello que el pueblo ofrece:

Aldea es un estado de alma, rabia diluida, angustia cuadrada como la plaza, gris como los tejados. Modorra y soledad, chisme (...). Los periódicos llegan tarde y cuando llegan ya todo ha sucedido, es otro pasado que puede olvidarse porque olvidar es cómodo. Estamos aldeados. (Mejía Vallejo 1980, 25)

En las tierras bajas del pueblo se encuentra el río, una corriente de aguas caprichosas y traicioneras que puede inundarlo todo. Es un lugar caluroso, húmedo, en el que viven animales ponzoñosos, insectos, frutas de colores luminosos y flores exuberantes, y donde se despiertan los deseos más ocultos. Aquí también encontramos una vivienda, la Casa del Río, construida por los Herreros en tiempos de la colonización. Quienes habitan este lugar dan rienda suelta a sus instintos más primarios; sus relaciones están marcadas por la violencia, la crueldad, el sexo desmedido y la pérdida de la razón: "En la distancia caída seguiría el río interminable, el bravo y el suave río, caudal de riberas feraces, de peces y troncos arrastrados por el invierno. Aguas turbias que verá el pequeño, aguas claras del verano, yerbas crecidas, sementales. La mala raza, todavía" (Mejía Vallejo 1990, 400). En la verticalidad espacial este sería el polo que toca la tierra en forma de caída y hundimiento. Las personas que están allí se van dejando llevar por el descarrío de sus afectos y el lugar se convierte en una gruta, una caverna tenebrosa en lo profundo de la tierra donde los sentidos se enajenan y no se puede ver más allá de sus paredes. El río sería así una antípoda del páramo.

La espacialidad cifrada en la verticalidad de la montaña está atravesada por una temporalidad cíclica que coincide con los tiempos de la naturaleza: floración, cultivos, lluvias y sequías. Estermann (2006) explica que las categorías temporales usadas en el pensamiento andino "no son 'avanzado' o 'atrasado', ni 'pasado' y 'futuro', sino 'antes' (ñaivpaq/nayra) y 'después' (qhepa/qhipa)” (197). En Balandú los seres humanos caminan de espaldas al futuro, con el pasado al frente a manera de guía: "«Nos vamos quedando atrás». / -El pasado también vive delante de nosotros..." (Mejía Vallejo 1980, 117). Los acontecimientos giran en redondo, se está en un constante regreso al primer día, como lo muestran las maldiciones que se actualizan en cada generación de los Herreros: "Las culpas llegan de Dios. Todo empezó con la primera maldición al primer Herreros, después en todos nosotros este aire resignado, esta cobardía. (...) Estamos viviendo el futuro de ayer, lo que planeamos, lo que temimos, lo irremediable de un tiempo sin límites" (Mejía Vallejo 1980, 182). Balandú es simbolizado por los Herreros como ese lugar donde todo inicia, muere y vuelve a renacer; es el no tiempo del espacio sagrado en la altura, el instante de la maldición de la aldea detenida, el tiempo como caída irremediable en el descenso al 
río desde donde se emprende una vez más el retorno al lugar del origen: la Casa de las dos Palmas.

En ese movimiento circular, la memoria es lo visible, aquello que se tiene ante sí como carta de navegación. Los personajes nos van haciendo entender que la vida depende de la posibilidad de ser recordados; existe aquello que se puede evocar, mientras si algo se olvida perece, así lo dice en un diálogo Elías Botero: "La muerte, pensaba, sería una pausa descansadora, el olvido cordial de lo vivido, el amable fin de la esperanza" (Mejía Vallejo 2002, 62). La familia Herreros se empeña en mantener vivo el pasado, para ello recuerda, canta las canciones de los abuelos, revisa álbumes fotográficos y se mira incansablemente en los espejos: "¿Hechos pasados? Pasamos nosotros. Si somos fieles sabemos que no hay hechos pasados. La gente queda en los espejos. Pequeños animales que nacieron para dar sombra fugaz, como nosotros" (Mejía Vallejo 1980, 60). El tiempo es entonces el tiempo natural, cíclico, que se intenta reordenar a través del ritual de los espejos, del cuidado de los muebles viejos o de la narración de las historias compartidas, y que nos muestra que la mirada se proyecta hacia lo ancestral, que el pasado está adelante.

Según la visión andina, espacio, tiempo y naturaleza confluyen, son una sola acepción (Pacha). El ser humano que habita la montaña es parte de ella, al igual que la flora y la fauna con los que comparte el entorno. Todo fue creado por la misma fuerza cósmica y, por tanto, cada forma de vida hace parte de la naturaleza y tiene una función diferente en ella. El hombre y la mujer andinos dan un valor especial al trabajo porque no lo entienden como castigo divino. Frente a la visión occidental, en los pueblos más tradicionales se entiende como la manera en que el ser humano participa del universo (Mejía Huamán 2005, 162-64). En la obra de Mejía Vallejo podemos apreciar un conflicto entre esta concepción y la mirada moderna occidental. Los personajes se debaten en una contradicción constante entre el amor a la tierra, el sentirse uno con ella, y los ideales de una sociedad que promueve los preceptos económicos capitalistas, dando un especial valor a la tierra porque simboliza dinero y poder. Esta pugna de fuerzas opuestas refleja el sentir de una parte de la sociedad que vive en los Andes, mostrando las complejidades del territorio.

Ahora bien, si dejamos entre paréntesis este conflicto, analizado en otros trabajos, podemos encontrar que parte de la poética del escritor se vincula con la mirada andina al animar objetos, animales y plantas. ${ }^{5}$ Sin recurrir al realismo mágico o a la fantasía, Mejía Vallejo nos presenta una realidad orgánica donde todo tiene una interrelación y cumple un papel. La topografía define el clima, la vegetación, los animales y las construcciones humanas; al mismo tiempo, el habitar modifica algunos aspectos de lo topográfico. El mismo autor ha mostrado su visión sobre el tratamiento de estos seres en diversas entrevistas:
Defiendo lo que me rodea y que la gente dice inanimado. Yo no creo que sea tan inanimado vivir en paz con estos seres, que hablen o que no hablen, que caminen o que estén quietos, que tengan patas o raíces, que produzcan una flor o un fruto. Cada uno tiene su idioma; debemos situarnos en eso y ser nada más que parte de la tierra. (Montoya 1984, 37)

Humanos, animales, plantas y objetos se relacionan en este universo literario como "amigos", indicando que establecen relaciones fuertes con estos otros seres, que interactúan con ellos como pares (López 2010). La composición estética de Balandú tiene la particularidad de mostrar un espacio constituido por formas de vida diversas y en comunión con el tiempo. Podemos entenderlo a través de esta visión de Efrén Herreros, donde el espacio refleja la comunión con los antepasados, el habitar la cordillera y la vivencia del tiempo desde el paisaje. La voz poética de Mejía Vallejo que apreciamos aquí recoge el tono de lo telúrico y de lo andino:

En días de sol, ese paisaje de viento y peñas fortalecía su ánimo, infundía otra dimensión de permanencia en las cosas. Olor de monte refrescaba sus años, canciones que venían de más allá con vigor de semillas, actos y voces de sus antepasados, los que trataban de darle una paz enemiga de su impulso inmediato [...] Entonces miraba el campo y en el campo otra dimensión del tiempo, paciencia del aire, paciencia del árbol en su crecimiento, paciencia de la orquídea y el clavel, paciencia de la montaña y el agua, que invitaba a una sosegada quietud. Paciencia de las nubes abiertamente mostradas, la del musgo en los claros del monte, el ritmo claro, el paso lento de los días sobre el farallón. (Mejía Vallejo 1990, 244)

\section{A modo de conclusión}

Manuel Mejía Vallejo se reconoce como un hombre afectado por el paisaje e inspirado por la memoria. Al describir su obra nos habla de una narrativa del recuerdo, señalando que su creación tiene como insumo principal afectos, imágenes e historias de su infancia. El territorio de la niñez regresa a manera de pueblo imaginario e impulso que lo motiva a contar las historias de los hombres de la cordillera. Sumándonos a sus reflexiones, podríamos decir que Balandú es un estado del alma, no un pueblo real. Balandú está cargado con valores simbólicos que hacen de él un espacio poético y lo sitúan como el epicentro de una obra artística, el eje articulador de una novela total.

La voz poética de Mejía Vallejo adopta el tono de la aldea, sus sentidos simbólicos. La narración se nutre de las imágenes de la materialidad terrestre: paciencia, dureza, trabajo, 
ascenso y descenso. La poética espacial se constituye a partir de casas que dan albergue y muestran la transformación de la materia en su propia construcción. Estas viviendas organizan el espacio de manera vertical conectando el cielo y la tierra, formando un eje que coincide con la prolongación de la montaña. Desde las casas, los personajes que habitan Balandú se relacionan con la naturaleza que los rodea como si fueran nidos que los integraran a un ecosistema del que participan animales, plantas, objetos y humanos. La visión del ser humano como copartícipe de la dinámica de la naturaleza se conjuga con la concepción del espacio situado entre dos polos -arriba y abajo- y del tiempo cíclico que constantemente renueva la vida, mostrándonos el pensamiento del hombre andino y la mirada del mundo desde la cordillera.

Balandú, el pueblo de balcones florecidos y cascoteo de caballos, es la imagen que da forma a la poética de Manuel Mejía Vallejo, le permite tejer los intereses y motivos que propiciaron sus meditaciones y le otorga una singularidad a su creación. A partir de la fuerza narrativa de Balandú, la voz de Mejía Vallejo recupera su tiempo desde una resonancia terrestre y andina.

\section{Obras citadas}

Bachelard, Gaston. 1958. El aire y los sueños: ensayo sobre la imaginación del movimiento. México: Fondo de Cultura Económica. . 1975. La poética del espacio. México: Fondo de Cultura Económica.

- 1978. El agua y los sueños: ensayo sobre la imaginación de la materia. México: Fondo de Cultura Económica.

2006. La tierra y las ensoñaciones del reposo: ensayo sobre las imágenes de la intimidad. México: Fondo de Cultura Económica.

Corbatta, Jorgelina. 2000. "Recordando a Manuel Mejía Vallejo: el hombre y su obra. Literatura y cultura." En Narrativa colombiana del siglo XX. Vol. 1, 367-83. Bogotá: Ministerio de cultura.

Durand, Gilbert. 1971. La imaginación simbólica. Buenos Aires: Amorrortu Editores.

2004. Las estructuras antropológicas del imaginario. México: Fondo de Cultura Económica.

Escobar, Augusto. 1997. Érase un viento... y en ese viento mi alarido: Memoria compartida con Manuel Mejía Vallejo. Medellín: Biblioteca Pública Piloto.

Estermann, Josef. 2006. Filosofía andina. Sabiduría indígena para un mundo nuevo. La Paz: Instituto Superior Ecuménico Andino de Teología.

Gallego-Duque, Félix. 2017. "Estudio diegético de la saga narrativa de Balandú en la obra de Manuel Mejía Vallejo.” En Manuel Mejía Vallejo: aproximaciones críticas al universo literario de Balandú, editado por E, Carvajal, 59-88. New York: Peter Lang.

. 2017a. "De la saga familiar a la saga narrativa: los Herreros y Balandú como ejes del proyecto literario de Manuel Mejía Vallejo." En Manuel Mejía Vallejo: aproximaciones críticas al universo literario de Balandú, editado por E. Carvajal, 35-58. New York: Peter Lang.

Huanacuni, Fernando. 2005. Visión cósmica de los Andes. La Paz: Editorial Armonía.

Lezama Lima, José. 1981. “Introducción a un sistema poético.” En El reino de la imagen. Editado por Julio Ortega, 258-79. Caracas: Biblioteca Ayacucho. 1981a. "Las imágenes posibles.” En El reino de la imagen. Editado por Julio Ortega, 218-37. Caracas: Biblioteca Ayacucho.

López, Alba Doris. 2010. "Objetos amigos en La Casa de las dos Palmas, una mirada a partir de la arqueología histórica”. Maestría en Hermenéutica Literaria (inédita), Universidad EAFIT, 
2011. "Un lugar para otear el mundo: La Casa de las dos Palmas del novelista colombiano Manuel Mejía Vallejo.” Boletín de Antropología. 25 (42): 175-202.

Mejía Arango, Juan Luis. 1996. “Lo importante es la canción.” En Manuel Mejía Vallejo. Tarde de verano, VI-XIII. Bogotá: Presidencia de la República.

Mejía Huamán, Mario. 2005. "Filosofía de la naturaleza." En Hacia una filosofía andina. Doce ensayos sobre el componente andino de nuestro pensamiento. 146-52. Lima: el autor.

Mejía Vallejo, Manuel. 1980. Tarde de verano. Bogotá: Plaza \& Janés.

1984. Y el mundo sigue andando. Bogotá: Planeta.

1985. “Escribo por instinto de conservación.” Revista Universidad Nacional (1944-1992) 1 (3): 3-4.

1990. La Casa de las dos Palmas. Bogotá: Planeta.

1994. Las noches de la vigilia. Medellín: Editorial UPB.

2002. Los invocados. Medellín: Biblioteca Publica Piloto.

2002a. La sombra de tu paso. Medellín: Biblioteca Publica Piloto.

2004. “Otras historias de Balandú”. En Cuentos completos. Bogotá: Alfaguara.

Montoya, Jaime. 1984. Manuel Mejía Vallejo: vida, obra y filosofía literaria. Bogotá: Talleres de Ediciones Avances.

Valéry, Paul. 1990. Teoría estética y poética. Madrid: Visor.

Vargas Llosa, Mario. 2007. “Cien años de soledad. Realidad total, novela total.” Cuadernos Hispanoamericanos, no. 681 (marzo): $9-12$.

\section{Notas}

1. Novelas de Balandú: Tarde de verano (1980), La Casa de las dos Palmas (1988), Los invocados (1997). Libros de cuentos: Las noches de la vigilia (1975) y Otras historias de Balandú (1990). Novelas urbanas donde aparece este universo ficcional: Aire de tango (1973), Las muertes ajenas (1979), Y el mundo sigue andando (1984), La sombra de tu paso (1987).

2. Los trabajos de Mauricio Vélez Upegui y de Rina Jaramillo muestran un tratamiento particular de la función de los objetos y su animismo en la obra de Mejía Vallejo. Referencio lecturas recomendadas para ampliar el tema: Vélez Upegui, Maurio. 1998. "Voces, objetos y recuerdos en Tarde de verano." Revista Universidad de Medellín, 67: 13-28. / Jaramillo, Rina. 2017. "Animismo simbólico en Las noches de la vigilia de Manuel Mejía Vallejo." En Manuel Mejía Vallejo: aproximaciones críticas al universo literario de Balandú, editado por E, Carvajal, 169-186. New York: Peter Lang.

3. Estos elementos coinciden con la acepción de Pacha, palabra quechua que reúne espacio, tiempo y naturaleza. Nos dice Mario Mejía Huamán que "pacha significa al mismo tiempo: mundo, espacio y tiempo; como tal, pacha, sería el conjunto de cosas que componen el universo, llamado en los Andes desde tiempos inmemoriales Pachamama. Sin embargo, pacha no puede reducirse a naturaleza, esto es a la significación material y física solamente, sino al mudo cultural y espiritual, el conjunto total de cosas que componen el universo" $(2005,149)$.

4. Esta mirada sobre el espacio narrativo de Balandú es insinuada por Juan Luis Mejía Arango (1996) y trabajada con mayor profundidad, posteriormente, por Alba Doris López (2011), Félix Gallego-Duque (2017a) y en el libro de mi autoría: Pueblo en vía de sueño. Balandú en la obra de Manuel Mejía Vallejo (en proceso de edición por la Editorial UPB). 
5. Hablo del trabajo de la profesora Claudia Patricia Acevedo sobre la familia Herreros. Acevedo, Claudia. 2005. "La familia Herreros: entre la trasgresión y el compromiso religioso." Estudios de Literatura Colombiana (16): 13-33. 